\title{
THE SUBVERSION OF ANCIENT THOUGHT: STRAUSS'S INTERPRETATION OF THE MODERN PHILOSOPHIC PROJECT
}

\author{
RICHARD R. OLIVEIRA \\ https:/ / orcid.org/0000-0001-9776-1006 \\ Federal University of São João del-Rei \\ Department of Philosophy \\ São João del-Rei-M. G. \\ Brazil \\ richardromeiro@hotmail.com
}

\author{
Article info \\ CDD: 320.1 \\ Received: 30.03.2020; Revised: 15.09.2020; Accepted: 16.09.2020 \\ https://doi.org/10.1590/0100-6045.2020.V43N3.RO
}

\section{Keywords \\ Political Hedonism \\ Exotericism \\ Enlightenment}

\begin{abstract}
The problem of modernity occupies a central place in the political reflection carried out by Leo Strauss. Taking this into account, the fundamental aim of this paper is to analyze how this author understood and questioned the philosophic project proposed by modern thinkers. In this sense, we will try to comprehend how, from Strauss's perspective, modernity, seeking to bring about in history the best political order through the abandonment of traditional esotericism and a radical politicization of philosophy, involves an ideal of rationalization of human life that is ultimately problematic for both society and philosophy.
\end{abstract}




\section{THE MODERN RUPTURE AND THE QUARREL BETWEEN THE ANCIENTS AND MODERNS}

According to Strauss's interpretation, the primordial experience that defined the character of premodern thought was essentially political, namely, the experience of the radically conflicting nature of the relations between philosophy and the city. As Strauss explains, every city (or political community) is based, indeed, on a set of authorized opinions, i. e., on a set of basic beliefs implicitly or explicitly sanctioned by the political authority, which intend to function as comprehensive answers to the most fundamental questions. Philosophy, however, originally consists in trying to replace opinions on fundamental questions for knowledge of fundamental questions, which is equivalent to saying that philosophy is originally, vis-à-vis the political order, a subversive intellectual activity. Taking into account these elements, one can easily see that the emergence of a conflict between philosophy and society is inevitable because philosophy, Strauss says, in its anti-doxastic exercise, seeks to destroy that principle which is the very element of social life: opinion (doxa) (Strauss, 1988a p. 11; see also p. 221). Now, for Strauss, the response of the political community to this threat caused by the outburst of the anti-doxastic activity of philosophy is the persecution, i. e., the act of harassing, prosecuting, and condemning those thinkers who dare to challenge the authorized opinions and convey heterodox or politically divergent teachings. From Strauss's perspective, to deal with this political problem and neutralize the risk of persecution, traditional philosophy had to formulate a new and differentiated method of communication: the literary technique of esoteric writing. ${ }^{1}$

\footnotetext{
${ }^{1}$ As is well known, this theme is the central subject of Strauss's famous work, Persecution and the Art of Writing, first published in
} 
Without going into more details here, it can be said that the literary technique of esotericism was, according to Strauss, in the context of traditional philosophy, an ironic rhetorical procedure through which ancient and medieval writers managed to transmit their potentially offensive thoughts in a disguised way, hiding subversive ideas under the guise of a politically edifying teaching which is capable of conforming itself to authorized opinions. This means that the literary technique of esoteric writing functioned, both in Antiquity and in the Middle Ages, as a tactic of accommodating the philosophic teaching to the moral atmosphere of society in order to mitigate the existing tension between philosophy and the city and provide a politically salutary presentation of the activity of philosophers. As a result of the use of this tactic, Strauss explains, ancient and medieval writers were able to conceal the most disturbing dimension of their intellectual investigations, neutralizing society's hostility towards them. ${ }^{2}$ Making his analysis more accurate, Strauss points out that, thanks to this sagacious concealment procedure carried out by esoteric writing, premodern philosophers have

1952. In the preface to this work (1988b, p. 5), Strauss clarifies that the fundamental proposal pursued by him throughout the book is to elaborate a "sociology of philosophy", taking as his main object of analysis the phenomenon concerning the problematic relations between philosophic thought and society.

${ }^{2}$ In his essay "On Classical Political Philosophy", which is part of the work What Is Political Pbilosophy?, Strauss, dealing with the problem of hostility against philosophy in the classical world, explains that in that world "the meaning of philosophy was by no means generally understood, and hence philosophy was distrusted and hated by many well-meaning citizens. Socrates himself fell victim to the popular prejudice against philosophy" (Strauss, 1988a, p. 93). 
succeeded, in fact, in producing a double effect, protecting at the same time philosophy from the risk of political persecution and the city from the more corrosive consequences of philosophic questioning. C. and M. Zuckert (2006, p. 132) draws our attention to this fundamental point of the Straussian interpretation of traditional philosophy by saying that, in Strauss's view, "esotericism was intended to protect or insulate philosophy and politics from each other. It protects the philosopher from persecution; it protects the city, to use Strauss's term, from the dissolving and irresponsible action of philosophy, which questions and challenges received opinion".

Strauss further clarifies that, to the extent that all esoteric writing was conceived and constituted in accordance with this political concern, all esoteric writing had to resort to a fundamental ambiguity in its composition, achieving in its literary organization two different levels of meaning: the exoteric one, which would be accessible to any reader and which is characterized by the agreement with the dominant political opinions, and the esoteric one, which contains the philosopher's subversive thoughts and which would be accessible only to those readers who are intellectually most gifted or prepared (Strauss, 1988b, pp. 33-37; 1988a, p. 212). ${ }^{3}$ For Strauss, this means that the premodern thinkers, resorting to the rhetorical expedient of esotericism, evidently chose to keep philosophy as a secret practice restricted to the few intellectually most prepared, who as such would

3 On this subject in Strauss's work, see McAllister (1995, pp. 8694), Lefort (2000, pp. 172-178), Sfez (2003, pp. 11-28), Pelluchon (2005, p. 16), Tanguay (2007, pp. 2-7, 69-74, 83, 96, 98), and C. and M. Zuckert (2006, pp. 41-44). It is worth noting here that the most complete and scholarly study of the literary phenomenon of esotericism in Western thought available today is that of Melzer (2014).

Manuscrito - Rev. Int. Fil. Campinas, v. 43, n. 3, pp. 1-54, Jul.-Sep. 2020. 
therefore be able to devote themselves to the life based on the experience of thought. In doing so, Strauss asserts, these thinkers refused thus to philosophy any pragmatic or banausic interest and were led to understand philosophic activity as a fundamentally proud and contemplative activity, whose realization brings the mind of those who dedicate themselves to it beyond the limits of political life and towards the knowledge of the eternal order. ${ }^{4}$

In Strauss's view, since premodern philosophers embraced this position, they considered that philosophic knowledge can never truly be popularized, which is why they cultivated a firm skepticism as regards to an eventual social spread of philosophy or science. Strauss makes clear that the reason for the adoption of this attitude of skepticism by premodern philosophers concerning the social diffusion of philosophy or science is found not in the defense of a snobbish elitism but rather in a consistent conception of nature, according to which nature works as a strict antiegalitarian order that separates the wise from the vulgar in an essential or non-accidental way. ${ }^{5}$ From the perspective of the

${ }^{4}$ For Strauss, this is one of the fundamental characteristics of premodern thought: the defense of the philosophic life as an essentially contemplative life, which, effecting the ascent of the human intellect to the understanding of the eternal order, transcends the parochial limits of political life. See Strauss (1971, pp. 151-152; 1978a, pp. 295-296; 1989a, pp. 250-251; 2013, pp. 198-199).

${ }^{5}$ In his essay "Reason and Revelation" (in Meier, 2006, pp. 146147), Strauss presents this aristocratic conception of philosophy that prevailed in the past as follows: "This view [the premodern view] of the relation of philosophy to life, i.e., to society, presupposes that philosophy is essentially the preserve of the very few individuals who are by nature fit for philosophy. The radical distinction between the wise and the vulgar is essential to the original concept of philosophy. The idea that philosophy as such 
Straussian interpretation, this means that for ancient and medieval authors not all men can raise themselves to the sphere of free-thinking or have true intellectual autonomy, which is tantamount to saying that a full rationalization of human life is ultimately an impossible event, so that the functioning of political society must be thought as something that will always be dependent on the predominance of some kind of opinion over the minds of most men.

But that is not all. As mentioned above, Strauss asserts that premodern philosophers, through the use of the literary technique of esoteric writing, aimed to mitigate the tension between philosophy and the city and forge a politically salutary presentation of philosophy, which as such would be able to conceal the most subversive and disturbing aspect of philosophic research. Now, according to Strauss, for ancient and medieval authors this politically salutary presentation of philosophy, which required the formulation of an "exoteric teaching" addressed to the general public, was "political philosophy" itself in its original meaning (Strauss, 1988b, pp. 17-18). Strauss explains, however, that although political philosophy thus understood had as its primary function to defend philosophy from possible political persecutions arising from its radical questioning of authorized opinions, it

could become the element of human life is wholly alien to all premodern thought. Plato demands that the philosophers should become kings; he does not demand that philosophy should become the ruler: in his perfect polity, only 2 or 3 individuals have any access whatever to philosophy; the large majority is guided by noble lies". Along the same lines, Strauss explains in Persecution and the Art of Writing (1988b, p. 34) that the premodern writers "believed that the gulf separating 'the wise' and 'the vulgar' was a basic fact of human nature which could not be influenced by any progress of popular education: philosophy, or science, was essentially a privilege of 'the few"'. 
was not limited, in the context of premodern thought, to this defensive rhetorical function, insofar as it had also a more assertive role, so to speak, and intended to provide the city with a "right guidance" concerning its values, principles, and practices (Strauss, 1988a, pp. 80-88). According to Strauss, developing this more assertive role of political philosophy, premodern philosophers have openly proposed that what justifies the existence of the political society is not an economic or material principle, such as private property or security, not even freedom, but rather the requirement of human excellence, so that the best political regime was conceived by these philosophers as the regime that seeks to bring about through its laws, customs, and institutions the virtue of its citizens (Strauss, 1971, p. 193; 1988a, p. 36-37). Here we find, from the perspective of Strauss's interpretation, the fundamental core of classical political teaching, which was organized entirely as a reflection on the character of the best regime, conceiving this regime as an aristocratic republic based on the principle of virtue (Strauss, 1988a, p. 40). Nevertheless, Strauss further teaches us that the skepticism of premodern thought manifests itself also here in a very meaningful way because, according to premodern thinkers, the coming into being of the best regime is not something achievable by human will, but rather an imponderable event that is subjected to fortune or chance, since its actualization is dependent on the highly improbable coincidence of wisdom and political power. For the ancient thought, man is not therefore the omnipotent master of the accidents and vicissitudes of history (Strauss, 1971, p. 139; 1988a, p. 34-35).

This was then, in Strauss's view, the general physiognomy of the philosophy in the past. Yet, Strauss explains, with the advent of modern thought a radical shift in this intellectual situation takes place, leading to a substantial change in the understanding of both what philosophy is, on the one hand, 
and of the nature of the relationships that philosophic reason has towards society or political life, on the other hand. For Strauss, what defines above all the spirit of modern thought is indeed a desire for rupture, that is, a desire to break in a radical way with the ancient philosophic thought by developing a conscious and deliberate reversal in the general theoretical orientation followed by that thought. ${ }^{6}$ In his article "The Three Waves of Modernity", Strauss explains this point as follows:

By modernity we understand a radical
modification of premodern political
philosophy - a modification which comes to
sight first as a rejection of premodern political
philosophy. If premodern political philosophy
possesses a fundamental unity, a physiognomy
of its own, modern political philosophy, its
opponent, will have the same distinction at
least by reflection. We are led to see this is in
fact the case after having fixed the beginning of
modernity by means of a nonarbitrary criterion.
If modernity emerged through a break with
premodern thought, the great minds who
achieved that break must have been aware of
what they were doing. (Strauss, 1989b, p. 83).

\footnotetext{
${ }^{6}$ We have here one of Strauss's favorite themes. McAllister (1995, p. 31) draws our attention to this by saying that "Strauss often wrote of the modern 'project'. The implication of this language is that modernity is characterized by goals that suggest a conscious break with classical understanding. The makers of modernity, therefore, took their bearings from the premodern tradition they rejected".
} 
This view of the disruptive character of modernity with regard to tradition is asserted by Strauss in various texts, such as, e. g., the essay "On the Basis of Hobbes's Political Philosophy", where he explicitly declares that "Modern philosophy emerged in express opposition to classical philosophy. Only in the light of the quarrel between the ancients and the moderns can modernity be understood" (Strauss, 1988a, p. 172). ${ }^{7}$ One of the ambitions of Strauss's philosophic research, as is well known, is to try to understand properly the meaning of this rupture in order to reopen the vexata quaestio concerning the "quarrel between the ancients and the moderns." 8 Strauss's conviction was that a well-

\footnotetext{
${ }^{7}$ See also the following remarks presented by Strauss in his famous essay "What is Political Philosophy?", which belongs to the work with the same title: "[...] in modern times, we find a great variety of fundamentally different political philosophies. Nevertheless, all modern political philosophies belong together because they have a fundamental principle in common. This principle can best be stated negatively: rejection of the classical scheme as unrealistic" (Strauss, 1988a, p. 40). Pangle (2006, p. 70) draws our attention to this important point of Strauss's understanding of the meaning of modern thought by remarking that, according to Strauss, "however intense are the mutual disagreements among the different stages and philosophic giants of modernity, all share a defining common ground in the rejection of the key elements in the classical outlook".

${ }^{8}$ Strauss took the phrase "the quarrel between the ancients and the moderns" from the aesthetic debate that arose in French Academy in the $17^{\text {th }}$ century about what kind of dramatic poetry was superior: classical or modern ("la querelle des anciens et des modernes", in French language). For Strauss, however, the real discussion goes far beyond the domain of aesthetics and has to do also with philosophy and science. In the lecture "Progress or Return?" included in the compilation entitled The Rebirth of Classical Political Rationalism, he explains this matter as follows: "[...] throughout the modern period, there has been a constant
} 
conducted analysis of the main philosophic tenets of this quarrel would provide us with insights that could allow us to realize both the problematic nature of the assumptions of the modern project and the tremendous intellectual and moral crisis originated by these assumptions ("the crisis of our time", in Strauss's phrase), opening a room for an eventual recovery of classical philosophy. ${ }^{9}$

movement against this modern trend. From the very beginning one phenomenon which is very well known, perhaps unduly wellknown - is the quarrel between the ancients and moderns at the end of the seventeenth century, which in its most well-known form was concerned with the relatively unimportant question of whether the French drama of the seventeenth century was really comparable to the classical drama. The real quarrel between the ancients and moderns did not concern the drama, of course, but concerned modern science and philosophy" (Strauss, 1989, p. 243).

${ }_{9}^{9}$ According to McAllister (1995, p. 24), we have in these two points - critique of modernity and recovery of classical philosophy - the essential elements of Strauss's philosophic project: "No thinker was more oriented to 'the crisis of the West' than Leo Strauss. One may see his entire career as a project with two parts: exposing the 'modern project' and recovering classical philosophy". See also the explanations proposed by C. and M. Zuckert (2006, p. 31). In the light of what has been said, it is important to remark here that the resumption of the study of the classical authors proposed by Strauss is not for him an innocuous antiquarianism or a procedure stemming from mere archeological curiosity but an intellectual necessity derived from the deep crisis in which the West finds itself nowadays. Just in the beginning of The City and Man (1978b, p. 1), Strauss makes this view clear as follows: "It is not self-forgetting and pain-loving antiquarianism nor self-forgetting and intoxicating romantism which induces us to turn with passionate interest, with unqualified willingness to learn, toward the political thought of classical antiquity. We are impelled to do so by the crisis of our time, the crisis of West" (emphasis in original).

Manuscrito - Rev. Int. Fil. Campinas, v. 43, n. 3, pp. 1-54, Jul.-Sep. 2020. 
This side of Strauss's work must be rightly understood, for it constitutes an evident source of copious misunderstandings about the philosophic meaning of the Straussian thinking. To begin with, it is important to note that Strauss's project of recovery of classical philosophy must not be interpreted as a desire to subvert the present status quo in order to restore a lost social order that would have existed in the past - a lost social order compared to which the modern society would appear as the very embodiment of the political evil. This means - and here we apprehend an essential point - that Strauss is not a reactionary. As is well known, the vocabulary of political theory sometimes lacks precision, so that the concepts that belong to it are once in a while subject to deep controversy. This is precisely what happens in some circumstances with the term "reactionary". Yet one can consider that Huntington's conception that a reactionary is first and foremost a radical who rejects present society and intends to carry out a "change backward" that will recreate an alleged "Golden Age" gives us a reasonable idea of this political type. In this sense, Huntington rightly remarks that a reactionary is

a critic of existing society who wishes to recreate in the future an ideal which he assumes to have existed in the past. He is a radical. No valid distinction exists between "change backward" and "change forward." Change is change; history neither retreats nor repeats; and all change is away from the status quo. As time passes, the ideal of the reactionary becomes less and less related to any actual society of the past. The past is romanticized, and, in the end, the reactionary comes to support a return to an idealized "Golden Age" which never in fact 
existed. He becomes indistinguishable from other radicals and normally displays all the distinctive characteristics of the radical psychology. (Huntington, 1957, p. 460).

As a closer reading of the Strauss's works can show us, none of these elements is found in Strauss's thought, and this fact obliges us to recognize that, contrary to what is often conveyed by certain interpreters, ${ }^{10}$ Straussian philosophic project is therefore immune to these two widespread ideological dangers that haunt the current Zeitgeist: political nostalgia and political radicalism. Concerning the first danger, it is worth mentioning here Pangle's remark (in Strauss, 1989a, p. xxiv), according to which Strauss's intellectual allegiance was not to the classical city or to classical art but rather to classical philosophy. This explains why Strauss, unlike Hannah Arendt, never expressed any intention to recover the ideal of vita activa and of "public space" of the ancient Greek polis. ${ }^{11}$ In regard to the second

10 This is the case, for example, of Lilla in his The Shipwrecked Mind (2016). Lilla, indeed, after having rightly departed from the primary distinction between "conservative" and "reactionary" (p. xii), erroneously interprets Strauss in the sequel of his analyses as one of the greatest exponents of the "reactionary mind" in the twentieth century, viewing Strauss as someone whose work would find itself under the influence of "the psychological power of political nostalgia".

11 See also Tarcov and Pangle (in Strauss; Cropsey, 1987, p. 928): "[...] in trying to keep glowing the embers of the older republican citizenship and statecraft, Strauss did not succumb to any kind of nostalgic longing for the polis and its vita activa, 'public space', or 'sense of community'. In this, Strauss differed not only from various contemporary leftist and rightist critics of liberal democracy but also from Machiavelli, Rousseau, Nietzsche, and other radical modern thinkers. Strauss's overriding allegiance was 
danger, it can be said that Strauss appears to be the very antipode of a radical, precisely because, being skeptical concerning the utopianism that is present in all political radicalism, he did not believe that there could be a political solution to the human problem. All political radicalism, whether left-wing or right-wing, rests indeed on the utopian belief that evil can be abolished from history: it suffices for this purpose, in the eyes of the radical political agent, that radical transformations of the social order are carried out with energy and resoluteness. Now, as anyone who knows Strauss's work can see, nothing further from the Straussian thought than this kind of voluntarism. As C. and M. Zuckert rightly remark (2006, p. 70), "Strauss [...] had very moderate political hopes and expectations". From Strauss's perspective, indeed, the deepest historical ills cannot be totally suppressed by human political efforts, however wellintentioned these efforts may be, which is tantamount to saying that politics will always remain something short of perfect reason and justice. In the "Introduction" to The City and Man (1978b, p. 5), Strauss points to this truth by saying that " $[\ldots]$ no bloody or unbloody change of society can eradicate the evil in man: as long as there will be men, there will be malice, envy and hatred [...]". This same idea is expressed in a more incisive way in the "Preface" to Spinoza's Critique of Religion (1997, p. 6), where Strauss says: "Finite, relative problems can be solved; infinite, absolute problems cannot be solved. In other words, human beings will never create a society which is free of contradictions". This philosophic insight into the limits of politics - something Strauss came to identify as a typical component of the

to classical philosophy, not to the classical city or even to classical art" (emphasis in original). The same position is found in Smith (in Zuckert, 2011, p. 77). 
classical political teaching, especially of Plato's ${ }^{12}$ - affords Straussian work a profound and austere sobriety, which finds its most eloquent expression in Strauss's conception of moderation as the principle that must rule man's expectations concerning the possibilities of historical and political change. ${ }^{13}$

Not being a "reactionary mind", Strauss distrusted therefore the ambitions of political radicalism and never cherished the nostalgic belief that history could be subverted in order to recreate the "Golden Age" of the past. It is in the light of this fact that we must interpret the Straussian project of recovery of classical philosophy. Here the first thing to do is to comprehend that, by trying to return to the classical authors from the crisis of our time, Strauss did not expect to find in their works ready-made doctrines or recipes to solve the moral and political problems that now afflict us. On the contrary, in Strauss's eyes, the return to the classics constituted rather a tentative or experimental procedure through which he expected to shed some light on the

\footnotetext{
${ }^{12}$ According to Strauss, the exhibition of the essential limits of the city is indeed the ultimate lesson that Plato's Republic presents to us: "Socrates makes clear in the Republic of what character the city would have to be in order to satisfy the highest need of man. By letting us see that the city constructed in accordance with this requirement is not possible, he lets us see the essential limits, the nature, of the city" (Strauss, 1978b, p. 138).

13 This is, as it were, the core of Strauss's political teaching. As Tarcov and Pangle (in Strauss; Cropsey, 1987, p. 934) explain, "it was his unflinching recognition of this deepest of all human tensions that led Strauss to teach on so many levels the need for a moderation of our political or moral or religious expectations. 'Human beings will never create a society which is free of contradictions". Concerning this subject, see also Pangle's remarks (2006, pp. 86-88).
}

Manuscrito - Rev. Int. Fil. Campinas, v. 43, n. 3, pp. 1-54, Jul.-Sep. 2020. 
intellectual and philosophic roots of our present predicament - something which would be for him only the first step in the process of finding out what would be the possible alternatives to a wholly new political situation that is proper to our age and that as such could not be entirely imagined by the classics (Smith, 2009, p. 5). In The City and Man, Strauss explains as follows this point:

The return to classical political philosophy is both necessary and tentative or experimental. Not in spite but because of its tentative character, it must be carried out seriously, i. e. without squinting at our present predicament. There is no danger that we can ever become oblivious of this predicament since it is the incentive to our whole concern with the classics. We cannot reasonably expect that a fresh understanding of classical political philosophy will supply us with recipes for today's use. For the relative success of modern political philosophy has brought into being a kind of society wholly unknown to the classics, a kind of society to which the classical principles as stated and elaborated by the classics are not immediately applicable. Only we living today can possibly find a solution to the problems of today. (Strauss, 1978b, p. 11).

As this important passage shows, Strauss does not conceive of the recovery of classical philosophy as an intellectual panacea that would magically dispel all the flaws that characterize the spiritual situation of our time. Rather, the recovery of classical philosophy constitutes for him a tentative experience whose primary scope is to try to bring a deeper understanding of the crisis in which we live. In 
Strauss's eyes, it is only after carrying out this philosophic procedure that we, who live here and now and are confronted with a political reality unknown to the ancients, can eventually come up with a solution to such a crisis.

\section{THE MODERN PROJECT: THE TRIUMPH OF REASON OVER NATURE AND Social Life, THE POLITICAL HEDONISM, AND THE EPICUREAN MOTIVE}

Having clarified the nature of Strauss's proposal to recover the classical thinking, we can now return to the main subject of this paper: Strauss's approach to modernity. As it was said before, according to Strauss, what defines first of all the spirit of modernity, from a strictly philosophic point of view, is the desire to break without hesitation with the traditional thought (classical and medieval) and its fundamental assumptions. Now, Strauss explains that this disruptive attitude of modern thought towards traditional thought expresses itself primarily as a radical change in the comprehension of the character and purpose of philosophic and scientific activity: in modernity, philosophy and science will no longer be understood, indeed, as a kind of thought essentially theoretical or contemplative, which proudly would raise itself above man's ordinary practical interests, but as an active enterprise whose fundamental goal is the increase of the human power and "the relief of man's estate" achieved by means of a successful control of nature. As Strauss asserts in The City and Man,

According to the modern project, philosophy or science was no longer to be understood as essentially contemplative and proud but as active and charitable; it was to be in the service of the relief of man's estate; it was to be 
cultivated for the sake of human power; it was to enable man to become the master and owner of nature through the intellectual conquest of nature. (Strauss, 1978b, p. 3-4).

But this is just one aspect of the question because, as Strauss rightly points out, this change in the understanding of the character of philosophy (and science) necessarily brings with itself a decisive shift both in the meaning of knowledge in general and in the comprehension of the character of that element which is the main object of knowledge: nature. From the modern point of view, indeed, knowledge is no longer represented as something passive or simply receptive, whose intellectual procedures would be subordinate to an objective and superior natural order, as was the case in the past, but rather as something fundamentally active and industrious, whereby man imposes the laws of his thought on a natural reality conceived as a rudimentary stuff. This means, in Strauss's eyes, that in the new conception of knowledge conveyed by modern thinkers, which affords primacy to man in the epistemological process, nature loses its former status of reality endowed with an intrinsic rationality and becomes henceforth a raw and senseless material for the operations of human reason a raw and senseless material that as such lacks any intelligibility in itself. In Strauss's words:

The new natural science differs from the various forms of the older one not only because of its new understanding of nature but also and especially because of its new understanding of science: knowledge is no longer understood as fundamentally receptive; the initiative in understanding is with man, not with the cosmic order; in seeking knowledge 
man calls nature before the tribunal of his reason; he "puts nature to the question" (Bacon); knowing is a kind of making; human understanding prescribes nature its laws; man's power is infinitely greater than was hitherto believed; not only can man transform corrupt human matter into incorrupt human matter, or conquer chance - all truth and meaning originate in man; they are not inherent in a cosmic order which exists independently of man's activity $[\ldots]$ The purpose of science is reinterpreted: propter potentiam, for the relief of man's estate, for the conquest of nature, for the maximum control, the systematic control of the natural conditions of human life. Conquest of nature implies that nature is the enemy, a chaos to be reduced to order; everything good is due to man's labor rather to nature's gift; nature supplies only the almost the worthless materials. (Strauss, 1989b, pp. 87-88).

From the modern point of view, knowledge is thus something created by man basically for the sake of power (propter potentiam) and must therefore carry out the triumph of human reason over a disordered and meaningless nature, which as such constitutes the major enemy of man. As the passage quoted above shows us, this triumphalist and very optimistic view of what knowledge is, which reduces nature to the condition of irrational stuff, presupposes that the source of all truth, all order, and all meaning lies ultimately in human understanding, and it is precisely this fact that affords to modern thought, according to Strauss, a radically anthropocentric character, in stark opposition to both the 
theocentric character of medieval thought and the cosmocentric character of classical thought. ${ }^{14}$

Now, Strauss remarks that within the modern project this triumphalist concept of rationality, which, as was explained, aims to promote "the relief of the man's estate" and to increase the human power, must be accomplished not only over nature but also in the political domain through the foundation of a society that affords worldly happiness to all its members. The central idea here is that man can create, thanks to the power of his reason, a regime or a political order capable of satisfying his mundane desires and interests, providing peace, comfort, and well-being for its associates. Strauss calls this modern view of the purpose of civil society "political hedonism" and sees Hobbes as the first author to present this new political doctrine in a more radical and systematic way. Hobbes, in Strauss's explanation, endorsed indeed the typically modern view of science as an instrument in the service of human desires and hence as a creation of man to effect the control of nature and increase his mundane power. As Strauss remarks in his first published work, Spinoza's Critique of Religion (1997, p. 90), for Hobbes "science exists for the sake of the power. In other words, science carries out the task of procuring means for the comfort and convenience of life". ${ }^{15}$ At the same time, the British

\footnotetext{
${ }^{14}$ On this subject, see the explanations provided by Strauss in his lecture "Progress or Return?" (1989a, p. 243-244).

${ }^{15}$ Later in this same work (p. 210), Strauss draws our attention again to this Hobbesian conception of science as a tool in the service of the fulfillment of human desire for power: "Hobbes rejects the conception of beatitudo propounded by the ethical thinkers of antiquity [i. e. Epicureans and Stoics], and replaces it by the prospect of endless progress from desire to desire, from power to ever greater power, and establishes, by reason of this conception of happiness, positive science as foundation of technology". On
} 
philosopher abandoned without hesitation classical political philosophy because, in full accordance with Machiavellian teaching, he regarded this philosophy as entirely idealistic, insofar as it distinguished the noble and just from the pleasant and conceived man as a political animal whose perfection or virtue constitutes the chief concern of civil society. From the Hobbesian perspective, these ideas have an altogether utopian character since their fundamental assumption is based on considerations concerning human perfection, which as such involve an ideal representation of the way men ought to live. Strauss points out that in vigorous contrast to this idealistic tradition Hobbes thought, following the path opened originally by Machiavelli's "realism", that a true science of politics, and therefore a true doctrine of moral or natural law, must be grounded on observations of how men actually live, which is tantamount to saying that a true science of politics must take into account in establishing its tenets not the ideal of man's perfection but the unmistakable role of passions and desires in ordinary human behavior, adopting this empirical evidence as the basic principle from which the right form of State organization can be deduced (Strauss, 1971, pp. 166-168, 177-181; 1988a, p. 48). Embracing this orientation and moving away from the "idealistic" tradition of classical political philosophy, Hobbes then, Strauss explains, "joins the Epicurean tradition" and accepts its hedonistic view according to which man is not a social or political being but a selfish, voluptuous, and apolitical animal by nature, who seeks tranquility or peace against the troubles of world and for whom the good identifies itself with the pleasant. Yet, Strauss adds, while the hedonism proper to the original Epicurean tradition was essentially apolitical and aimed to

this subject, see also Strauss's explanations in Natural Right and History (1971, p. 175).

Manuscrito - Rev. Int. Fil. Campinas, v. 43, n. 3, pp. 1-54, Jul.-Sep. 2020. 
achieve, through a radical critique of religious fears, not civil peace but private peace, or peace of mind, understanding happiness (eudaimonia) first and foremost as a state of inner tranquility, ${ }^{16}$ Hobbes's hedonism will acquire an unprecedented political dimension, since for Hobbes the search for peace and happiness cannot be any longer restricted to the individual but must necessarily assume the character of a collective project, becoming as such the basis of a new conception of the civil society. Strauss clarifies this important aspect of Hobbes's thought as follows:

[...] Hobbes joins the Epicurean tradition. He accepts its view that man is by nature or originally an a-political and even an a-social animal, as well as its premise that the good is fundamentally identical with the pleasant. But he uses that a-political view for a political purpose. He gives that a-political view a political meaning. He tries to instill the spirit of political idealism into the hedonistic tradition. $\mathrm{He}$ thus became the creator of political hedonism, a doctrine which has revolutionized human life everywhere on a scale never yet approached by any other teaching. (Strauss, 1971, p. 169).

Strauss considers that this political hedonism elaborated by Hobbes will become the primary moral basis of modern

16 "For Epicurus the primary and principal good is inner tranquility", Strauss says in this sense in Spinoza's Critique of Religion (1997, p. 61). As regards the original Epicureanism as a philosophic movement characterized by the "concern for the peace of mind", see also Strauss's valuable explanations in the same work (pp. 37-52).

Manuscrito - Rev. Int. Fil. Campinas, v. 43, n. 3, pp. 1-54, Jul.-Sep. 2020. 
political thought, providing, as it were, the guiding inspiration for what is its most emblematic and authentic expression in the field of philosophy: the Enlightenment. The decisive point here, in Strauss's view, is that underlying the modern philosophic project there is a genuinely "Epicurean motive" whose main purpose is to effect the positive pursuit of happiness and peace in this world by liberating man from the irrational and hence harmful influence of religious beliefs (we will return later to this important element - the critique of religion - in the characterization of modern philosophic project). This "Epicurean motive" is not to be reduced, in Strauss's view, to the doctrine originally developed by Epicurus, but must be rather understood as a certain attitude of spirit (or as a certain "mood"), which expresses itself first of all by a natural interest in the achievement of human happiness conceived fundamentally as a life of pleasure. ${ }^{17}$ In this sense, Strauss explains that the "Epicurean motive", which constitutes the phenomenon of Epicureanism in its broadest meaning, is "the most universal human motive" for insurgence against religion and hence "the original inclination of the human heart - an inclination of the heart which found its classical expression in the philosophy of Epicurus" (Strauss, 1997, p. 42; 51).

However it may be, the main point Strauss intends to emphasize, as was explained, is that, as opposed to the private or non-political character of the original Epicureanism developed by Epicurus and his school, modern Epicureanism will be resolutely political, having as its main goal the creation of a social order capable of engendering civil peace. (Strauss, 1997, p. 51; 86). Tanguay (2007, p. 40) sheds light on this aspect of Strauss's

17 See Strauss's explanations in his Die Religionskritik des Hobbes (2008, p. 315-316).

Manuscrito - Rev. Int. Fil. Campinas, v. 43, n. 3, pp. 1-54, Jul.-Sep. 2020. 
interpretation of modern thought by saying that for Strauss "the essentially private motive of Epicureanism is modified by the active and enterprising character of the modern Enlightenment. The peace envisaged by the modern Enlightenment is a peace both civil and general".

According to Strauss, Hobbes was the first modern author to develop this new version of Epicureanism more systematically, having endeavored to integrate this Epicureanism into the philosophic framework of political realism proposed by Machiavelli. With this goal in mind, Hobbes sought then to demonstrate that the moral principle to be taken into account in the task of explaining the State and its organization is not virtue, as the classics erroneously taught, but that passion which is most powerful in man's nature, namely, the desire for self-preservation, which manifests itself negatively as fear of violent death. Following this reasoning, Hobbes accordingly asserts that civil society and government are established chiefly to put an end to the primal terror of death felt by man in the state of nature and to ensure therefore his self-preservation in a most safe and comfortable way. In this sense, Strauss explains (1988a, p. 48) that, in Hobbes's view, "the terror of fear of death stands at the cradle of civil society [...] Once government has been established, the fear of violent death turns into fear of government. And the desire for self-preservation expands into the desire for comfortable self-preservation".

Strauss argues that Hobbes resolutely tried to take this "pedestrian hedonism" to its ultimate conclusion. In order to do so, he was forced to abandon the ascetic orientation of ancient Epicureanism, with its conception of happiness as a state of repose, its emphasis on self-restraint, and its restriction on unnecessary desires, considering all this as unrealistic demands, and sought to foster an unprecedented emancipation of the human desire for comfort. This emancipation, Strauss says (1971, p. 189), has totally changed 
the understanding of the nature and purpose of civil society since "it required, above all, that the function of civil society be radically redefined: 'the good life', for the sake of which men enter civil society, is no longer the life of human excellence but "commodious living". As a result, thanks to this new political teaching, the primary task of government was reformulated and started to be thought of as a function subordinated to the human desire for welfare, pleasures, and material benefits, and no longer as an instrument for cultivating man's soul in view of what is noble and good. Quoting Hobbes, Strauss clarifies that, by virtue of this crucial theoretical shift, "[...] the sacred duty of the rulers is no longer 'to make the citizens good and doers of noble things' but to 'study, as much as by laws can be effected, to furnish the citizens abundantly with all good things which are conducive to delectation"' (Strauss, 1971, p. 189).

For Strauss, Hobbes's decisive claim is that from the application of the principles explained above, which integrate the theoretical framework of his "political hedonism" and which involve, as we have seen, the firm rejection of the principles of traditional political philosophy, the social problem can finally be solved, making possible the establishment of a commonwealth able to satisfy the human desire for self-preservation, peace, and comfort. In other words, Hobbes's decisive claim is that the right social order can be actualized by man in this world, evincing the triumph of his reason in the practical or political domain. For this purpose, in Hobbes's eyes, it suffices that political philosophy leaves behind its original aspiration for human perfection and all the demands of moral discipline associated with it, and constitutes itself from the knowledge of that which is most elementary or lowest in man, i. e., the passions, focusing primarily, among the passions, on that one which is the most powerful of all, namely, the fear of violent death, which is but, as was explained, the other side of the visceral 
urge for self-preservation. In short, the Hobbesian belief is therefore that the right social order can be established through the efficient manipulation of passions, a procedure which makes possible a control over human behavior that corresponds to the technical control that natural science gets over nature. Strauss highlights this essential point of Hobbes's political philosophy as follows:

Man as the maker of civil society can solve once and for all the problem inherent in man as the matter of civil society. Man can guarantee the actualization of the right social order because he is able to conquer human nature by understanding and manipulating the mechanism of the passions. (Strauss, 1971, p. 194). ${ }^{18}$

As it was said before, in the context of the Straussian explanation, Hobbes's political hedonism constitutes undoubtedly an essential philosophic component of the modern project. Drury (2005, p. 136) draws our attention to this fact by remarking that, in the interpretation elaborated by Strauss, "political hedonism gives the whole of modernity its character". ${ }^{19}$ For Strauss, indeed, what is proper to the modern project taken in its entirety, as we have also seen, is

\footnotetext{
18 See also what Strauss asserts at p. 200 of the same work.

19 Tanguay (2007, p. 101) goes in the same direction and also points to the Strauss's conception about the extraordinary influence exerted by Hobbes's thought on modernity: "Hobbes therefore resolutely turns away from the utopianism of the ancients and of the Bible to devote himself to the establishment of a real world where order, peace, and security will reign. According to Strauss, Hobbes succeeded in his project since the liberal world is our world and the founder of authentic liberalism is Hobbes".
} 
precisely the intent to establish the empire of human reason not only over nature but also over social life in order to fulfill man's mundane desires for comfort and promote by this means human happiness in this world. Rational control of nature and rational control of social life are thus in this scheme only the two sides of the same coin. Strauss remarks that Hobbes himself, in fact, had already conveyed this idea by presenting the mentioned elements as two closely interconnected procedures, since in his view the establishment of a commonwealth able to provide its citizens with all the benefits of a comfortable life is possible thanks to the fact that "there are no knowable limits" to the human conquest of nature (Strauss, 1971, p. 175). In this sense, Hobbes's political teaching appears then as an eloquent expression of the most genuine spirit of modernity.

Be that as it may, taking into account the main points of the Strauss's interpretation of the meaning of modernity that we have synthetically presented here, it can be said that in Strauss's view the phenomenon of technology plays a fundamental role in the molding of modern ethos. If by technology we mean, in effect, a set of skills and methodical procedures by which man achieves the rational control of things, as opposed to magic, then we can say that for Strauss the essence of modernity is technological. ${ }^{20} \mathrm{It}$ is in the light of this point that we must interpret Strauss's assertion that

${ }^{20}$ See the following remarks from C. and M. Zuckert (2006, p. 34): "Modern philosophers, even those prior to Nietzsche, had insisted that there was no superhuman, independently existing order or source of morality, because they wanted to improve the human condition. To improve that condition significantly, Strauss maintained, they thought it would be necessary to manipulate nature, even to transform it entirely [...] Strauss thus began to suspect, as Heidegger was to argue later, that the core or essence of modern philosophy was technological."

Manuscrito - Rev. Int. Fil. Campinas, v. 43, n. 3, pp. 1-54, Jul.-Sep. 2020. 
in modernity "the political problem becomes a technical problem" (Strauss, 1989b, p. 87). Now, being essentially technological, modernity is ultimately characterized, in Strauss's eyes, by a tremendous political and civilizational ambition, namely, the ambition to control and completely rationalize human life and its conditions (which includes nature, of course) in order to create in this world a prosperous, free, and just society which, having become truly universal thanks to the progress of history, will embrace in its final stage all humanity (Strauss, 1978b, p. 4). ${ }^{21}$

\section{THE ABANDONMENT OF ANCIENT EsoteriCism AND THE RADICAL Politicization OF PHILOSOPHY}

Strauss points out that this rationalizing ambition of modernity goes hand in hand with the idea tacitly assumed by modern authors according to which the actualization of the right social order is not a spontaneous historical event but something that depends decisively on the action of philosophy, which must thus become a mundane and completely politicized activity, capable of functioning as a genuine instrument for the transformation of history. In other words (and here we apprehend a very crucial point of Strauss's interpretation), for the modern authors the achievement of the project of establishing a fully rationalized and free society, which would embrace in its final stage all humanity, is possible only if philosophy abandons its traditionally reserved approach towards society and assumes itself as an essentially political activity whose fundamental aim is the accomplishment of the historical change. In Natural Right and History, Strauss refers to this radical

21 This Straussian view of the meaning of modernity fits very well with that proposed by McAllister. Cf. McAllister (1995, p. 14).

Manuscrito - Rev. Int. Fil. Campinas, v. 43, n. 3, pp. 1-54, Jul.-Sep. 2020. 
politicization suffered by philosophy in modernity as follows:

$[\ldots]$ in the modern centuries philosophy as such had become thoroughly politicized. Originally, philosophy had been the humanizing quest for the eternal order, and hence it had been a pure source of humane inspiration and aspiration. Since the seventeenth century, philosophy has become a weapon, and hence an instrument. It was this politicization of philosophy that was discerned as the root of our troubles by an intellectual who denounced the treason of intellectuals. (Strauss, 1971, p. 34).

Strauss explains that this radical politicization of philosophy effected by modernity consists basically in the fact that in modern times philosophy ceases to be an esoteric and contemplative activity, with its cautious and prudential attitude regarding society, and becomes more and more an active, radically public, and even revolutionary enterprise which intends to promote the enlightenment of all men through an unprecedented procedure of pamphletary and widespread dissemination. The main goal of modern philosophers with the adoption of this political voluntarism is to effect the conversion of all men to the cause of the progress and thus engender the radical change of the established social order. This means, in Strauss's eyes, that the achievement of modern project is inseparable of a resolute transformation of philosophy into a radically exoteric activity, which demands evidently the relinquishment of ancient esotericism (with its secretive and fundamentally contemplative conception of rationality) and the alliance of philosophic knowledge with propaganda with a view to enlightening the people and educating the multitude - 
something that represents an indispensable procedure to accomplish the necessary historical improvement of society. ${ }^{22}$ According to Strauss, it is precisely this desire to fully publicize philosophy and therefore to make philosophic knowledge completely political and hence exoteric in order to promote thereby a radical rationalization of humanity and social life that characterizes the spirit of modern Enlightenment, as opposed to the spirit of traditional philosophy. ${ }^{23}$

For Strauss, the author in which for the first time appears this new and revolutionary view of philosophy as a radically politicized activity, aiming at the transformation of the social order and the refounding of the political community, is Machiavelli. In the exegesis elaborated by Strauss, Machiavelli is indeed the thinker who, for the first time in Western intellectual history, resolutely rejects the ancient

22 As Tanguay explains (2007, p. 112), "what Strauss means polemically by propaganda is the Enlightenment project of emancipating men through the diffusion of science and knowledge". Concerning the importance of propaganda thus understood as one of the main tools that modern Enlightenment will use to promote the harmonization of philosophy and society, see the following explanations conveyed by Strauss in Thoughts on Machiavelli (1978a, p. 297): "The new philosophy [i. e., modern philosophy] lives from the outset in the hope which approaches or equals certainty, of future conquest or of conquest of the future in the anticipation of an epoch in which the truth will reign, if not in the minds of all men, at any rate in the institutions which mold them. Propaganda is to guarantee the coincidence of philosophy and political power. Philosophy is to fulfill the function of both philosophy and religion".

23 Concerning the essentially exoteric character of modern Enlightenment, as opposed to the essentially esoteric character of traditional philosophy, see the remarks presented by Strauss in his book Philosophy and Law (1995, pp. 102-103).

Manuscrito - Rev. Int. Fil. Campinas, v. 43, n. 3, pp. 1-54, Jul.-Sep. 2020. 
ideal of philosophy as an essentially contemplative activity and converts philosophy into an instrument of political practice whose fundamental goal is the gradual subversion of the current situation, aiming at the establishment of a new political order in which man can at last guarantee the fulfilment of his worldly interests concerning safety, power, and glory. This means, from the Straussian perspective, that with Machiavelli's thought philosophy loses its traditional reference to a suprapolitical standard (the contemplative life) and confines itself definitively in the immanence of the city, subordinating itself henceforth to the pragmatical purposes of the people or demos. Strauss presents this mutation operated by Machiavelli in the meaning and purpose of philosophy as follows:

Machiavelli's philosophizing [...] remains on the whole within the limits set by the city qua closed to philosophy. Accepting the ends of the demos as beyond appeal, he seeks for the best means conducive to those ends. Through his effort philosophy becomes salutary in the sense in which demos understands, or may understand, the salutary. He achieves the decisive turn toward that notion of philosophy according to which its purpose is to relieve man's estate or to increase man's power or to guide man toward the rational society [...] (STRAUSS, 1978a, p. 296).

With Machiavelli, we witness therefore an unprecedented intellectual transformation that reduces philosophy to a servant of politics (ancilla politicae), which makes philosophic knowledge from now on a simple tool for the achievement of the worldly goals of society and demos. In this sense, Machiavelli begins thus the break with tradition and is, in 
Strauss's eyes, the true founder of modernity. ${ }^{24}$ According to Strauss, this unprecedented politicization of philosophy in Machiavelli, which constitutes the inaugural landmark of modernity, is shown above all in the fact that Machiavelli was the first author to consider that the radical change of society needed for the establishment of "new modes and orders" requires first and foremost the resolute publicization of philosophy, i. e., requires the gradual suppression of the ancient esotericism, with its aristocratic conception of knowledge, and the audacious and boundless dissemination of philosophic teaching among the people or the multitude. It is true that Strauss recognizes that Machiavelli is an author who still writes esoterically and who masters, with great skill, the peculiar technique of the traditional art of esoteric writing; however, from the Straussian perspective,

${ }^{24}$ That is what Strauss says explicitly, e. g., in the essay "What is Political Philosophy?" (1988a, p. 40) in the following terms: "The founder of modern political philosophy is Machiavelli. He tried to effect, and he did effect, a break with the whole tradition of political philosophy". At an earlier stage of his career, Strauss held, however, a different position, considering that Hobbes, not Machiavelli, was the true founder of modernity. This is what he says, e. g., in his youth work, Die Religionskritik des Hobbes (2008, p. 268): "Hobbes ist der Begründer der modernen Politik. Er selbst hat fur sich in Anspruch genommen, dass er als erster die Politik in den Rang einer Wissenschaft erhoben habe; und wenigstens, dass seine Politik eine unerhorte Neuerung sei, haben voller Bewunderung oder voller Entsetzen ihm seine Zeitgenossen zugestanden". Yet as he deepened his research on modern political thought, getting a better knowledge of Machiavelli's work, Strauss acknowledged the error of this interpretation, although he has maintained the view of the central place occupied by Hobbes in the elaboration of the modern philosophic project. Concerning this subject, see Strauss's remarks in the "Preface" to the American edition of his The Political Philosophy of Hobbes (1963, p. xv).

Manuscrito - Rev. Int. Fil. Campinas, v. 43, n. 3, pp. 1-54, Jul.-Sep. 2020. 
Machiavelli uses the devices of the traditional art of esoteric writing to convey a subversive teaching that is radically antitraditional and that as such intends to make esoteric literature an obsolete method of communicating philosophic knowledge. According to Strauss, this is perhaps the great paradox of Machiavelli's teaching, a paradox that he mentions in Thoughts on Machiavelli as follows:

Time and time again we have become bewildered by the fact that the man who is more responsible than any other man for the break with the Great tradition should in the very act of breaking prove to be the heir, the by no means unworthy heir, to that supreme art of writing which that tradition manifested at its peak. (Strauss, 1978a, p. 120).

Taking his reading of Machiavelli's work further, Strauss asserts that, since Machiavelli wanted to subvert the ancient esotericism and effect the most widespread popularization of philosophy in order to influence the mind of the people or demos, he came to be the first philosopher to propose, in a conscious and courageous way, the strategic union of philosophy with propaganda. In this sense, Strauss clarifies that Machiavelli thought that, thanks to propaganda understood essentially as the widespread diffusion of philosophic teaching which makes the procedures of philosophic mind socially dominant, the coincidence of political power and philosophy so desired by the classics as the sine qua non condition for the actualization of the best regime could finally be effected, making therefore possible the historical coming into being of the rational social order. In the context of the Straussian analysis, this means that Machiavelli can be seen as the true beginner of that philosophic movement that is the most characteristic 
intellectual phenomenon of modern times: the Enlightenment. As Strauss explains in his Thoughts on Machiavelli,

Classical political philosophy had taught that the salvation of the cities depends on the coincidence of philosophy and political power which is truly a coincidence - something for which one can wish or hope but which one cannot bring about. Machiavelli is the first philosopher who believes that the coincidence of philosophy and political power can be brought about by propaganda which wins over ever larger multitudes to the new modes and orders and thus transforms the thought of one or a few into the opinion of the public and therewith into public power. Machiavelli breaks with the Great Tradition and initiates the Enlightenment. We shall have to consider whether that Enlightenment deserves its name or whether its true name is Obfuscation. (Strauss, 1978a, p. 173).

Strauss points out that behind these Machiavellian conceptions about the actualization of the best political order through the use of propaganda and the radical politicization of philosophy we find the fundamental belief that supports Machiavelli's entire political project, namely, the belief that, contrary to what the classics had thought, chance is not a completely imponderable and mysterious phenomenon but something that can be dominated by human will. Chance (Fortuna), Machiavelli indeed teaches, is a woman who can be mastered by the use of force, so that the coming into being of the best regime is an event achievable by human power. This fundamental point of 
Machiavelli's teaching, in the Straussian view, constitutes another intentional break with the classical political philosophy since, as we have seen, the advent of the best regime depends ultimately, according to classical political philosophy, on chance, and chance is not, from the perspective of classical authors, something that could be controlled by man. Machiavelli rejects this traditional capitulation of man before chance and boldly proclaims the supremacy of human power vis-à-vis historical contingency (Strauss, 1983, p. 213; 1989b, p. 84-85). But this is not all. Strauss further remarks that Machiavelli sought to make his thesis about man's supremacy over chance more plausible and guarantee therefore the actualization of the best regime by using a decisive philosophic maneuver, namely, the abandonment of the principle of virtue as the supreme reference of politics and the consequent lowering of the standards by which social action is understood. By lowering the standards by which social action is understood, Machiavelli expected to increase indeed the human control over politics and therefore strengthen the probability of the advent of a more rational political order. For Machiavelli, thus, it is all about rejecting the "idealistic" or "utopic" orientation of traditional philosophy, with its concern for human perfection, and about trying to understand politics as it is or from the ordinary interests and purposes that really moves men and societies in their historic existence.

There is something fundamentally wrong with an approach to politics which culminates in a utopia, in the description of a best regime whose actualization is highly improbable. Let us then cease to take our bearings by virtue, the highest objective which a society might choose; let us begin to take our bearings by the objectives which are actually pursued by all 
societies. Machiavelli consciously lowers the standards of social action. His lowering of the standards is meant to lead to a higher probability of actualization of that scheme which is constructed in accordance with the lowered standards. Thus, the dependence on chance is reduced: chance will be conquered. (Strauss, 1988a, p. 41).

For Strauss, this revolutionary change made by Machiavelli in the understanding of the question concerning chance and the actualization of the best regime, as well as in the nature and purpose of philosophy, will shape the spirit of modern thought and is therefore at the basis of the political project that characterizes that thought. It can be briefly said, however, that the fundamental point of Strauss's interpretation of Machiavelli is ultimately the idea that Machiavelli begins modernity, from a philosophic point of view, first and foremost because he modifies profoundly and decisively the way philosophy relates to society. According to Strauss, Machiavelli would have indeed thought that the first procedure to be carried out to make philosophy politically effective would be to disconnect philosophy from its pure contemplative ambitions and to politicize it in a resolute way. By virtue of this procedure, philosophic knowledge would then be transformed into something essentially public or exoteric, which through the gradual transformation of the minds of men would engender the required historical change, contributing hence to the foundation of "new modes and orders". We have in this conception a very important change in the approach of philosophy in its relationship with society, a change which will be the core of the modern Enlightenment.

Taking his reflection forward, Strauss furthermore shows us that this decisive change in the attitude of philosophy 
regarding society carried out by Machiavelli and modern Enlightenment relies ultimately on the optimistic belief that it is really possible, thanks to the progress of popular education and the exoteric propagation of knowledge, to convert philosophy into the element of society and thereby replace the kingdom of general darkness by the republic of universal light. This means, from the modern point of view, that the conflict between philosophy and social life, on the one hand, and the political phenomenon of persecution associated to it, on the other hand, are not natural or immutable facts but rather historical accidents which derive from "the faulty construction of the body politic." 25 In other words, for modern Enlightenment, the antagonism between philosophy and the city is not essential, that is, something that would belong to the very nature of things, but a mere byproduct of the historical prevalence of an obscurantist social order that keeps men in a sub-rational condition. Accordingly, it is perfectly possible to achieve a final harmony between philosophy and society and thereby overcome the obscurantist social order by resorting to a

\footnotetext{
${ }^{25}$ As Strauss remarks in Persecution and the Art of Writing (1988b, p. 33), "what attitude people adopt toward freedom of public discussion, depends decisively on what they think about popular education and its limits. Generally speaking, premodern philosophers were more timid in this respect than modern philosophers. After about the middle of the seventeenth century an ever increasing number of heterodox philosophers who had suffered from persecution published their books not only to communicate their thoughts but also because they desired to contribute to the abolition of persecution as such. They believed that suppression of free inquiry, and of publication of the results of free inquiry, was accidental, an outcome of the faulty construction of the body politic, and that the kingdom of general darkness could be replaced by the republic of universal light".
}

Manuscrito - Rev. Int. Fil. Campinas, v. 43, n. 3, pp. 1-54, Jul.-Sep. 2020. 
massive diffusion of knowledge, i. e., as Machiavelli had already taught, by resorting to propaganda. ${ }^{26}$

This Enlightenment conception will become, in Strauss's eyes, the basis of modern democracy, and will be responsible for the emergence of the belief "in the possibility of the simply rational society, i. e. of a society each member of which would be of necessity perfectly rational so that all would be united by fraternal friendship, and government of men, as distinguished from administration of things, would wither away" (Strauss, 1978b, p. 38). Here we find undoubtedly a conception of man and social life that lies at the opposite end of the view held by the classical and medieval writers, for which philosophy, as we have seen before, could never become a really popular and thoroughly socialized discipline. In this sense, Strauss explains in Persecution and the Art of Writing (1988b, p. 34) that these writers "believed that the gulf separating 'the wise' and 'the vulgar' was a basic fact of human nature which could not be influenced by any progress of popular education: philosophy, or science, was essentially a privilege of 'the few". From this contention one can then recognize that, from the perspective of traditional thought, the modern

${ }^{26}$ Commenting on this topic of Strauss's reflection, Tanguay (in Coppens et al., 2014, p. 48) points out opportunely that, in Strauss's view, the radically exoteric character of modern Enlightenment is based precisely on the assumption that there is a fundamental harmony between philosophic knowledge and social life: "Selon lui [Strauss], les Lumières modernes sont exotériques parce que elles sont habitées d'une volonté d'émancipation universelle inconnue de la philosophie ancienne et médievale. L'idéal moderne étant de faire de chaque individu un sujet rationnel autonome ou un philosophe, il requiert pour sa réalisation une diffusion universelle du savoir et des idées philosophiques émancipatrices. Il se fonde sur la préssuposition d'une harmonie entre le savoir et la societé".

Manuscrito - Rev. Int. Fil. Campinas, v. 43, n. 3, pp. 1-54, Jul.-Sep. 2020. 
project of a complete popularization of philosophy by means of its radical politicization and the suppression of ancient esotericism is nothing other than a tremendous mystification, since for traditional thought philosophy, by its very nature, can never be transformed into the element of human life.

It should be noted that, according to Strauss, this shift carried out by modern thought towards a radical exotericism and therefore towards an unprecedented politicization of philosophy, with a view to enlightening the people and thereby promoting the rationalization of social life, is in the last analysis explained by the abandonment of the classical ideal of contemplative life and by the corresponding assertion of a primacy of practical reason over theoretical reason. In an essay dedicated to the medieval Jewish philosopher Maimonides that belongs to his work Philosophy and Law, Strauss highlights this point by saying that "the exoteric character of the modern Enlightenment is based on the conviction - prevalent long before its formulation, foundation and radicalization by Kant - of the primacy of practical reason". ${ }^{27}$ This important feature of modern Enlightenment (and others that we have seen before) reveals to us therefore that, in Strauss's eyes, the quarrel between the ancients and the moderns arises in the field of philosophy first and foremost as a discussion about the meaning and scope of rationality, a fact that allows us to assert that the modern project can be interpreted in its most general lines, from a philosophic point of view, as Pelluchon rightly

27 As Tanguay (in Coppens et. al., 2014, p. 49) explains, "la querele des Anciens et des Modernes que Strauss a voulu rouvrir aurait ainsi pour enjeu souterrain le rapport de la raison théorétique et de la raison pratique et, plus particulièrement, le primat de l'une ou de l'autre de ces instances".

Manuscrito - Rev. Int. Fil. Campinas, v. 43, n. 3, pp. 1-54, Jul.-Sep. 2020. 
observes (2005, p. 277), as the proposition of a new rationalism.

\section{The ANTI-Theological IRE AND The MEANING OF THE CRITIQUE OF RELIGION IN MODERN THOUGHT}

This new rationalism proposed by the moderns, which raises the claims of practical reason over the disinterested aims of theoretical reason, has evidently, as one can easily see, a voluntarist character, insofar as it intends to subvert an old social order considered obscurantist and obsolete and reshape the political conditions of human life. As C. and M. Zuckert explain (2006, p. 61), this means that in modernity, according to Strauss, "philosophy thus becomes particularly eager to have an effect- to remake the world". Now, Strauss clarifies that, in the view of modern Enlightenment, the historical success of this voluntarist proposal, whose aim is to effect the rationalization of men and social life, necessarily requires a systematic intellectual attack on what was the chief institutional basis of traditional society: religion and the theological-political power through which religion exercises its control over community life. For moderns, religion and theological-political power tyrannize indeed the human mind and are then the main mechanisms responsible for keeping men in a condition of ignorance and indigence. This implies that religion and theological power both work therefore, due to their obscurantist social influence, as the main causes of what Hobbes and the major exponents of the Enlightenment call "the kingdom of darkness". It follows from this that the task of enlightening men and establishing "the simply rational society", that is, the society in which all human beings will be "perfectly rational" and enjoy happiness, peace, and well-being, requires first of all the development 
of a vigorous critique of religion and its theological-political power. This is, according to Strauss, the true common ground that ultimately unites all modern thinkers, regardless of their divergences concerning the most specific matters: the intellectual campaign launched resolutely against the "kingdom of darkness". In Strauss's words (1978a, p. 231): "We no longer understand that in spite of great disagreements among those thinkers [i. e., the modern thinkers], they were united by the fact that they all fought one and the same power - the kingdom of darkness, as Hobbes called it; that fight was more important to them than any merely political issue".

From Strauss's perspective, these elements show us that the political project of modern thought is undoubtedly animated by a violent "anti-theological ire", ${ }^{28}$ i. e., by a virulent rebellion against religious orthodoxy and its social influence, with a view to building in this world a civilization based in the autonomy of man and his culture (Strauss, 1995, p. 21-39). What must be done therefore, according to modern Enlightenment, is to shake off the theological yoke that has oppressed man's spirit for centuries in order to make man the true master of his history and fate. Taking this key point of the Straussian interpretation of modernity into account, Tanguay (2007, p. 108) explains that "Strauss characterized the spirit of the modern break as being moved essentially by anti-theological ire, by which he meant that the modern project was constructed over and against the old theological outlook that persuaded men to recognize laws of which they were not themselves the authors" (emphasis in original). Here we can notice a truly outstanding characteristic of the "Epicurean motive" that represents, in

28 The phrase "anti-theological ire" occurs in the essay "What is Political Philosophy?", in the context of an analysis of Machiavelli's political thought. See Strauss (1988a, p. 44).

Manuscrito - Rev. Int. Fil. Campinas, v. 43, n. 3, pp. 1-54, Jul.-Sep. 2020. 
Strauss's eyes, as was explained, the fundamental moral stimulus underlying the whole development of modern philosophy. Strauss makes clear that the critique of religion is indeed for Epicureanism the primary philosophic procedure for achieving peace of mind and happiness in this world, and this is precisely what we see, in a paradigmatic way, in the classic doctrine originally formulated by Epicurus. ${ }^{29}$ In this sense, Strauss remarks that

Epicurus is truly the classic of the critique of religion. Like no other, his whole philosophy presupposes the fear of superhuman forces and of death as the danger threatening the happiness and repose of man; indeed, this philosophy is hardly anything but the classical means of allaying the fear of divinity [Numen] and death by showing them to be 'empty of content'. (Strauss, 1995, p. 35).

In the context of the Straussian analysis, this Epicurean critique of religion, whose aim is "allaying the fear of divinity and death", will become the primary inspiration of the modern "anti-theological ire" directed against religious orthodoxy. ${ }^{30}$ However, Strauss highlights at the same time a

\footnotetext{
${ }^{29}$ On this, see, once again, the explanations provided by Strauss in the first chapter of his Spinoza's Critique of Religion, chapter whose title is precisely "The Tradition of the Critique of Religion" (1997, pp. 37-52).

${ }^{30}$ In this regard, Strauss explains (1995, pp. 35-36) that "the Epicurean critique is the foundation, or more exactly the foreground, of the Enlightenment critique". Tanguay (2007, p. 109) explains this point of the Straussian interpretation of modernity as follows: "The modern critique of religion was not the product of spontaneous generation. From his first works on,
} 
fundamental difference that separates the critique of religion characteristic of Epicurus's teaching from the critique that is specifically modern. This difference can be presented as follows: whereas for the classical doctrine of Epicurus religion must be fought because it is a source of terrors and fears that endanger the tranquility of mind, for the moderns the attack on religion must be carried out because of the consoling character of religious beliefs. In other words, from the modern perspective, the battle against religion has to be performed not because religion fills the human soul with disturbing dreads concerning the actions of jealous and unappeasable gods but because religion cradles the mind of men with sweet, comforting, and delusional hopes. ${ }^{31}$ Now, precisely because of its consoling and delusional character, religion prevents men, according to modern Enlightenment, from confronting the harshness of their mundane situation and, by feeding their minds with reveries concerning a supernatural life, divert them from the painful task of taking the reins of their destiny in their own hands and conquer a nature that is essentially hostile to them. In short, as one of the most ardent or exalted exponents of modernity will later asserts, religion is an opium and as such must be fought so that man can become at last the master of his history and build on this earth the social and civilizing structure that will make his happiness possible. This means that the modern critique of religion is intrinsically associated to a political project, which shows us, once again, how Epicureanism in

Strauss saw in this critique the reactivation of themes from the Epicurean critique. The Epicurean critique of religion is, for Strauss, the very source of the Enlightenment, even if its spirit was substantially modified by the moderns".

31 Concerning the difference between the critique of religion developed by Epicurus and that of moderns, see the valuable clarifications provided by Pelluchon (2005, pp. 84-85). 
modernity undergoes a radical politicization, becoming the fundamental basis of an ambitious ideal of civilization in which the triumph of the human reason over nature and social life is the essential goal. Strauss explains these crucial points of his interpretation of the philosophic meaning of modernity in a long and decisive passage of Philosophy and Law that I would like to quote here:

The Epicurean critique thus undergoes an essential change in the age of the Enlightenment. Of course for the Enlightenment too, and just precisely for the Enlightenment, it is a question of man's happiness, his peace of mind, which is threatened preeminently or exclusively by religious ideas. But the Enlightenment understands this happy peace, this tranquility, in a fundamentally different way from the original Epicureanism - it understands "tranquility" in such a way that the civilization, the subjection, the improvement of nature, and particularly of human nature, becomes indispensable for its sake. While the battle of the Epicureans against the terrifying delusion of religion was aimed preeminently at the terror of this delusion, the Enlightenment aimed preeminently at the delusoriness itself: regardless of whether the religious ideas are terrifying or comforting - qua delusions, they cheat men of the real goods, of the enjoyment of the real goods; they steer men away from the real "this world" to an imaginary "other world", and thus seduce them into letting themselves be cheated of the possession and enjoyment of the real, "this-worldly" goods by 
the greedy clergy, who "live" from those delusions. Liberated from the religious delusion, awakened to sober awareness of his real situation, taught by bad experiences that he is threatened by a stingy, hostile nature, man recognizes as his sole salvation and duty not so much "to cultivate his garden" as in the first place to plant himself a "garden" by making himself the master and owner of nature. This "crude" conception has long since been "overcome", of course, by a conception which completely exposes the self-proclaiming and self-betraying tendency in the transformation of Epicureanism into the Enlightenment. The latest and purest expression of this is that the religious ideas are rejected not because they are terrifying but because they are desirable, because they are comforting: religion is not a tool which man has forged for dark reasons in order to torment himself, to make life unnecessarily difficult, but rather a way out chosen for very obvious reasons, in order to escape the terror and the hoppelessnesss of life [...] (Strauss, 1995, pp. 36-37).

From these considerations presented by Strauss, one can see then how Epicureanism really undergoes, in the modern context, a radical change, becoming, from a movement that seeks first and foremost the peace of mind in a life on the fringes of civil society, something deeply politicized. Talking about this decisive change, Strauss (1997, p. 29-30) remarks that the civilizational enterprise that modern philosophy aims to achieve "requires, above all, political action, revolution, a life and death struggle: the Epicurean who wishes to live securely and retiredly must transform himself 
into an 'idealist' who has learned to fight and die for honor and truth". Now, this unprecedent politicization of Epicureanism, which transforms the retired Epicurean into an idealistic political agent, presupposes the adoption of an audacious intellectual approach that boldly converts atheism into a public teaching, breaking with the traditional precaution of classical and medieval philosophy on this subject. Quoting an excerpt from Burke's Thoughts on French Affairs, Strauss (1971, p. 169) points to this distinctive feature of the modern thought as follows: "Boldness formerly was not the character of atheists as such' [...] Political atheism is a distinctly modern phenomenon. No premodern atheist doubted that social life required belief in, and worship of, God or gods". One can say, following the line of this Straussian interpretation, that by adopting such an audacious political atheism, modernity reveals at last its Promethean face and shows us therefore its ambition to act like the ancient Greek titan, seeking to promote the emancipation of man through a radical revolt against the divine authority.

\section{CONCLUSION}

We have seen in the previous pages some important points of the Straussian understanding of the meaning of modernity. Roughly speaking, we have noticed that, in the context of Strauss's analysis, modernity is characterized, above all, by a civilizational project that intends to overcome the obscurantist political order of the past and to effect a complete rationalization of human life - a rationalization that would engender the final triumph of reason over both nature and social life. This means that modernity, in the context of Straussian interpretation, is driven by a radical political voluntarism whose main purpose is "to remake the world". The historical achievement of this purpose, which is 
the very soul of the modern project, depends, however, Strauss further explains, on a decisive break with the traditional thought and hence on a substantial change in the way philosophy approaches society and its beliefs and institutions. According to the modern authors, indeed, in order to promote the desired rationalization of human life and therefore create "the simply rational society", philosophy must cease to be a secretive, contemplative, and politically cautious activity, whose intellectual procedures would be restricted only to a few men, and become a public, enterprising, and politically engaged movement, capable as such of educating the people and enlightening society. As was explained before, by means of this profound change, which requires the abandonment of the ancient esotericism and the resolute transformation of philosophy into a radical exoteric activity, designed as such to wage a public fight against the "kingdom of darkness" and the theologicalpolitical power that sustains it, the moderns believe that the old conflict between philosophy and society would finally be abolished, which would pave the way for the inexorable victory of reason in the domains of human history and nature, leaving behind an era of superstition, ignorance, and religious obscurantism.

From Strauss's point of view, this whole project, which defines philosophically the spirit of the modern Enlightenment, has a profoundly problematic character, notwithstanding its unequivocal philanthropic motivation. This occurs first of all, in Strauss's eyes, because the modern authors, in their obstinate political voluntarism, neglect an elementary and constant evidence that decisively characterizes everywhere what concerns human condition, i. e., the irreducible intellectual difference that separates, by nature, the wise from the vulgar. We have here, according to Strauss, an anthropological truth that cannot be suppressed by any kind of social engineering or progress of 
popular education and which puts us before the inescapable experience concerning the constitutive inequality that characterizes human nature as such, regardless of all possible historical transformations. These considerations, as one can see, show us two important things concerning the Straussian comprehension of modernity: first, they reveal us that Strauss understood very well that behind the modern Enlightenment project lies a radically egalitarian conception of man, which founds the modern ambition of popularizing the intellectual procedures proper to philosophy and science; 32 secondly, they evince at the same time that the Straussian strategy to question this extreme modern egalitarianism is to resort to the primary phenomenon already identified by the classics of the radically heterogenous character of men with regard to intellectual gifts and aptitudes. ${ }^{33}$ This is undoubtedly a crucial idea for understanding the spirit of the Straussian reflection, an idea to which Tanguay (2007, p. 140) points out by saying that "Strauss accepts the thesis of the natural inequality of men. Moreover, he does not seek to lessen or to soften its consequences. Men are fundamentally unequal in their ability to pursue wisdom, which by nature is man's highest good".

For Strauss, this is however just one aspect of the question since, according to him, the problematic nature of the modern project also manifests itself in the fact that its fundamental purpose of "remake the world" by radically

32 About the modern egalitarianism, see what Strauss says in The City and Man (1978b, p. 40-41).

33 For Strauss, this conception of the radical differences between men concerning intellectual gifts constituted an essential component of the original concept of philosophy. In his essay "Reason and Revelation" (in Meier, 2006, p. 146), he says that "the radical distinction between the wise and the vulgar is essential to the original concept of philosophy".

Manuscrito - Rev. Int. Fil. Campinas, v. 43, n. 3, pp. 1-54, Jul.-Sep. 2020. 
politicizing philosophy turns out to be in the last analysis an essentially harmful maneuver to both society and philosophy. On the one hand, the intention of radically politicizing philosophy is indeed problematic for society because it aims to suppress from the functioning of social life that political element that is, in Strauss's eyes, its most primary and strongest foundation, namely, opinion. Strauss's idea concerning this subject is that no society can survive without certain salutary and steady opinions about morality and justice, which as such acquire therefore an authorized character in the context of political life, becoming, as it were, the very spiritual atmosphere in which this political life takes place. In this sense, Strauss asserts in Natural Right and History (1971, p. 12) that "men cannot live, that is, they cannot live together, if opinions are not stabilized by social fiat. Opinion thus becomes authoritative opinion or public dogma or Weltanschaaung". However, philosophic questioning, Strauss argues, has always a corrosive effect on these authoritative opinions, insofar as it engenders, in its obstinate search for truth, the inevitable undermining of all moral beliefs that sustain the political order of the city. This means, from Strauss's perspective, that there is a really insoluble opposition between society's need for stabilized opinions or dogmas and the questioning procedure of philosophy as a zetetic activity, an opposition that shows us that no society can ultimately become truly rational. Tarcov and Pangle summarize this point of the Straussian teaching as follows:

True opinion - a faith, a loving dedication, a rootedness in one's own age or people that surmounts all doubts - is what all political societies, and almost all individuals, need, as the spiritual air they breathe. Genuine rationalism - rooted in knowledge of 
ignorance, possessed by eros for the eternal truth, in its heart longing to flee the atmosphere of the cave - can as a result never become the direct basis of any political or even cosmopolitan society. (Tarcov; Pangle in Strauss; Cropsey, 1987, p. 934).

According to Strauss, the modern thought would be blind to this phenomenon and its attempt to make philosophy completely public and therefore to bring about "universal enlightenment" could only have as a consequence the permanent and dangerous destabilization of the whole social life. On the other hand, Strauss thinks that the demand of completely popularizing philosophy, that is, of rendering philosophy something that is fully exoteric and public, is also problematic for philosophy itself because this demand, by turning philosophic activity into a mere instrument of propaganda and indoctrination of the masses in the service of a political agenda, promotes a debasement or a vulgarization of this activity that affects adversely the intellectual freedom that is necessary of its exercise. In other words, in the context of modern project, philosophy, in Strauss's eyes, ends up being "tyrannized by the interests of society" and becomes therefore ideology, losing consequently its autonomy and its noetic radicality, which causes its inevitable degradation into a mere opinion that, in the clashes of the public arena, is entirely subdued by a political ideal. Such a phenomenon represents for Strauss the very death of philosophy since, from the Straussian perspective, the exercise of philosophic activity presupposes as its conditio sine qua non a radical intellectual independence regarding the domain of political opinions and social dogmas.

To conclude this text, I would like to note that these Straussian questionings to modernity and its philosophic 
project, which were presented here succinctly, may be regarded by some as a reflection of excessive purism, if not of hateful elitism. However, I believe that they have nowadays an indisputable relevance because, at a time like ours, when political passions threaten to drag away all things and frenzied radicalism, under the most different party flags, unfortunately has free course, philosophy is more than ever exposed to the dangers of militant ideologization and political instrumentalization. Strauss's reflection, which is an attempt to defend first and foremost philosophy and not a political cause, ${ }^{34}$ encourages us to think about these dangers and platonically invites us to understand that philosophy is possible only under the most radical freedom of thought, which requires necessarily the overcoming of the passionate opinions that mobilize men in the political disputes carried out in the cave of history.

\section{REFERENCES}

\section{Strauss's Works.}

STRAUSS, L. The Political Philosophy of Hobbes. Its Basis and its Genesis. Chicago: University of Chicago Press, 1963 [1936].

. Natural Right and History. Chicago: University of Chicago Press, 1971 [1953].

- Thoughts on Machiavelli. Chicago: University of Chicago Press, 1978a [1958].

34 See Bloom (1974, p. 377).

Manuscrito - Rev. Int. Fil. Campinas, v. 43, n. 3, pp. 1-54, Jul.-Sep. 2020. 
. The City and Man. Chicago: University of Chicago Press, 1978b [1964].

- "The Mutual Influence of Theology and Philosophy". The Independent Journal of Philosophy, vol. 3, pp. 111-118, 1979.

. "On the Interpretation of Genesis". L'Homme, 21, pp. 5-20, 1981.

- Studies in Platonic Political Philosophy. Chicago:

University of Chicago Press, 1983.

- What Is Political Philosophy? And Other Studies. Chicago: University of Chicago Press, 1988a [1959].

- Persecution and The Art of Writing. Chicago: University of Chicago Press, 1988b [1952].

. "Progress or Return?" In The Rebirth of Classical Political Rationalism. Edited by Thomas L. Pangle. Chicago: University of Chicago Press, 1989a.

. "The Three Waves of Modernity". In An Introduction to Political Philosophy. Ten Essays by Leo Strauss. Edited with an introduction by H. Gildin. Detroit: Wayne State University Press, 1989b, pp. 81-98.

. Philosophy and Law. Contributions to the Understanding of Maimonides and his Predecessors. Translated with an introduction by Eve Adler. Albany: State University of New York Press, 1995.

. Spinoza's Critique of Religion. Chicago: University of Chicago Press, 1997 [1965].

. "Reason and Revelation (1948)". In MEIER, H. Leo Strauss and the Theologico-Political Problem. Cambridge: Cambridge University Press, 2006. 
. Hobbes' politische Wissenschaft und zubörige Schriften. Briefe. Herausgegeben von Heinrich und Wiebke Meier. Stuttgart-Weimar: Verlag J. B. Meztler, 2008 [2002].

. On Tyranny. Corrected and expanded edition. Including the Strauss-Kojève correspondence. Chicago: University of Chicago Press, 2013 [1961].

\section{Books About Leo Strauss and Other Secondary Sources.}

BLOOM, A. "Leo Strauss. September 20, 1889-October 18, 1973”. Political Theory, vol. 2, n. 4, pp. 372-392, 1974

DRURY, S. The Political Ideas of Leo Strauss. Updated Edition. Lexington: Palgrave Macmillan, 2005 [1987].

HUNTINGTON, S. P. "Conservatism as an Ideology". The American Political Science Review, 51 (2), pp. 454-473, 1957.

LEFORT, C. “Three Notes on Leo Strauss". In idem. Writing the Political Text. Transl. David Ame Curtis. Durham, London: Duke University Press, 2000, pp. 172-206.

LILLA, M. The Shipwrecked Mind. On Political Reaction. New York: New York Review Books, 2016.

MCALLISTER, T. V. Revolt Against Modernity. Leo Strauss, Eric Voegelin, and the Search for a Postliberal Order. Lawrence: University Press of Kansas, 1995.

MELZER, A. Philosophy Between the Lines. The Lost History of Esoteric Writing. Chicago: University of Chicago Press, 2014. 
PANGLE, T. L. "Editor's Introduction". In STRAUSS, L. The Rebirth of Classical Political Rationalism. Edited by Thomas L. Pangle. Chicago: University of Chicago Press, 1989a, pp. vii-xxxviii.

. Leo Strauss. An Introduction to bis Thought and Intellectual Legacy. Baltimore, Maryland: The Johns Hopkins, 2006.

PELLUCHON, C. Leo Strauss: une autre raison, d'autres lumières. Essai sur la crise de la rationalité contemporaine. Paris: J. Vrin, 2005.

SFEZ, G. Leo Strauss, lecteur de Machiavel. La modernité du mal. Paris: Ellipses, 2003.

SMITH, S. B. "Leo Strauss Today". In idem (ed.), The Cambridge Companion to Leo Strauss. Cambridge: Cambridge University Press, 2009, pp. 1-12. - "Philosophy as a Way of Life: The Case of Leo Strauss". In ZUCKERT, C. (ed.). Political Philosophy in the Twentieth Century. Cambridge: Cambridge University Press, 2011, pp. 61-79.

TANGUAY, D. Leo Strauss: An Intellectual Biography. Trans. Christopher Nadon. New Haven, CT: Yale University Press, 2007. - "Leo Strauss et les Lumières modernes". In COPPENS, Frederic at al. (eds.). Leo Strauss. À quoi sert la philosophie politique. Paris: PUF, 2014, pp. 47-66.

TARCOV, N.; PANGLE, T. L. "Epilogue. Leo Strauss and the History of Political Philosophy". In STRAUSS, L.; CROPSEY, J. (eds.). History of Political Philosophy. Chicago: University of Chicago Press, 1987 [1963], pp. 907-938. 
ZUCKERT, C.; ZUCKERT, M. The Truth about Leo Strauss. Political Philosophy and American Democracy. Chicago: University of Chicago Press, 2006.

$($ (c) $\mathrm{BY}$ 